\title{
Taraxacum sect. Erythrosperma in Slovakia. Part I. Addenda to distribution of Taraxacum cristatum
}

\section{Matej Dudáš}

Institute of Biology \& Ecology, Faculty of Science, P. J. Šafárik University, Mánesova 23, SK-041 54, Košice, Slovakia, dudas.mato@gmail.com

Dudáš M. (2019): Taraxacum sect. Erythrosperma in Slovakia. Part I. Addenda to distribution of Taraxacum cristatum. - Thaiszia - J. Bot. 29 (1): 051-059.

Abstract: New distribution data of Taraxacum cristatum ( $T$. scanicum group), described in the year 2005, in Slovakia were recorded. During the intensive study of Slovak dandelions in herbarium collections and field course, additional 22 localities were found. The species has been recorded in 17 phytogeographical districts up to now, with the highest frequency in the western and the southern part of the country, preferring dry and xerothermic steppe grasslands, pastures and dry meadows from the class Festuco-Brometea. The altitudinal maximum in Slovakia, in $668 \mathrm{~m}$ a. s. I. was recorded in the Strážovské vrchy Mts. on the top of Mt. Baba. The updated distribution map is attached.

Keywords: dandelion, Central Europe, xerothermic habitats, Taraxacum scanicum group.

\section{Introduction}

Taraxacum cristatum Kirschner, Štěpánek \& Vašut, Preslia 77: 204, 2005 is a member of Taraxacum scanicum group belonging to Taraxacum sect. Erythrosperma. It is a central European triploid apomictic taxon distributed in the Czech Republic (southern Bohemia and Moravia), Austria (Lower Austria), northern Hungary, southwestern Poland and Slovakia (Vašut et al. 2005; Marciniuk et al. 2009). From the area of Slovakia, Vašut et al. (2005) published 
12 records mostly from western Slovakia (mainly from Záhorská ní̌ina Lowland and the Strážovské vrchy Mts. and their surroundings) and two records from the Slovenský kras Karst. Other data on the species distribution in the southern Slovakia from the Slovenský kras Karst and Ipel'sko-rimavská brázda Region (8 records) were listed by Šuvada (2010), Šuvada et al. (2012) and partly mentioned (9 records) by Majeský et al. (2015).

The main aim of the study is (1) to summarize the knowledge on the species distribution based on the author's own field research and the additional excerption of voucher specimens from the Slovak public herbaria and literary sources, (2) to describe the biology and ecology in Slovakia and (3) to prepare the map of the actual distribution.

\section{Material and methods}

The study and the field research were performed in the years 2012-2018. As the source of the new species records, the specimens from the Slovak (BRA, $\mathrm{KO}, \mathrm{NI}, \mathrm{SAV}, \mathrm{SLO}$ and TM), the Hungarian (BP) and the Czech public herbaria (BRNU and PRC) were used, while in many other Czech and Slovak herbaria no specimens from the studied area were found. The herbarium codes follow Thiers (2019). The distribution map was prepared in the program ArcGis, version 9.2. The mapping grid follows the traditionally used CEBA (Central European Basic Area) grid template described by Niklfeld (1971). The list of the revised specimens has the following arrangement: phytogeographical district (Futák 1980), the nearest village, the description of the locality; in parenthesis: the collector, the date of collection, the acronym of the herbarium collection where the specimen is deposited and the number of the specimen (if exists). Literary sources are cited in the References chapter and follow the abridged form: the author(s), the year of publication and the page with Taraxacum cristatum record. The localities within the phytogeographical districts are listed from west toward east. The own herbarium specimens of the author are deposited in the Herbarium of the Botanical Garden of Pavol Jozef Šafárik University in Košice, Slovakia (acronym $\mathrm{KO}$ ) and in the Palacký University in Olomouc, the Czech Republic (acronym OL). The taxonomy and nomenclature of Taraxacum follows Kirschner \& Štěpánek (1995) and Vašut (2003). The names of the syntaxa follow Jarolímek et al. (2008). 


\section{Results}

Based on the study of voucher specimens in the public herbaria collections not mentioned by Vašut et al. (2005) and own field course, the 22 further localities in Slovakia were found.

In total, Taraxacum cristatum has been recorded in 47 locations belonging to seventeen phytogeographical districts and subdistricts (of 31 ) in the western, southern and eastern part of the country (Fig. 1). Of those, 26 locations are situated in seven districts of the area of the Pannonian flora (Pannonicum) and 21 locations in ten districts of the Carpathian flora (Carpaticum). The altitudinal maximum in Slovakia was $668 \mathrm{~m}$ a. s. I. It was recorded in the Strážovské vrchy Mts. on the top of Mt. Baba. The most preferred soil type recorded were sands and sandy soils, humid mold between limestone, less volcanic substrates and rarely loess. The detailed list of the recorded localities in Slovakia follows.

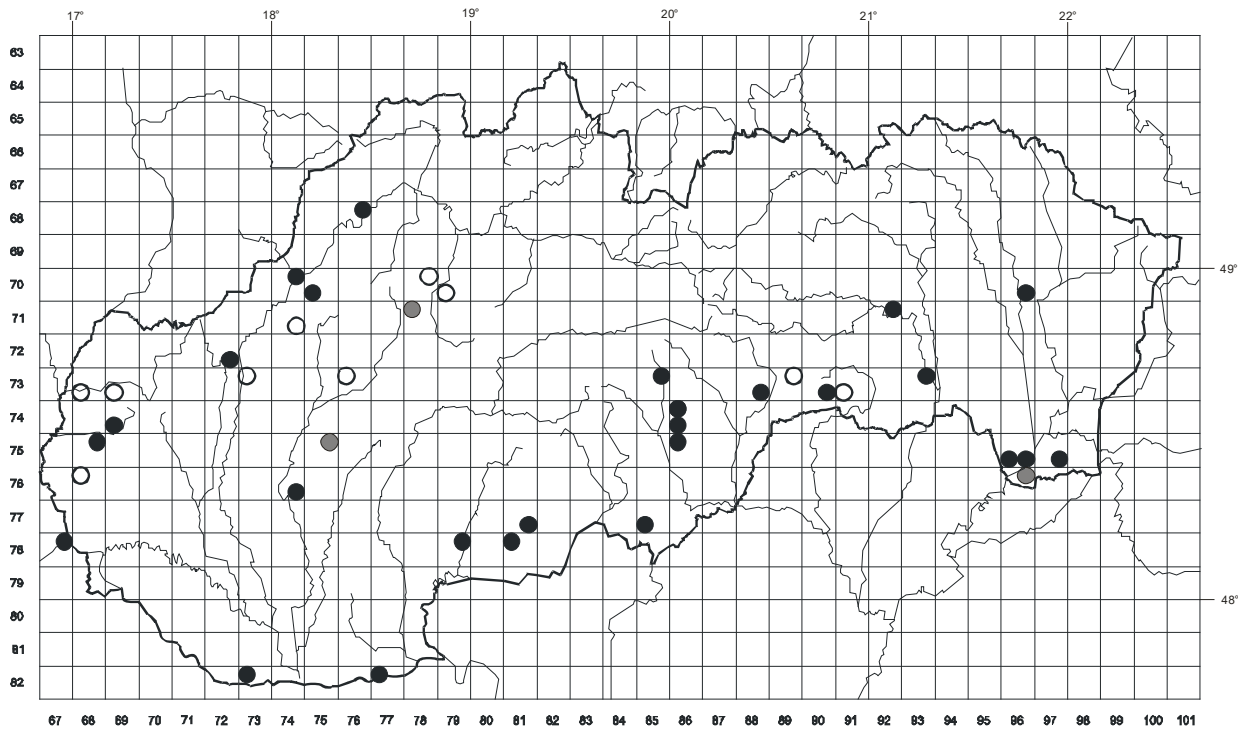

Fig. 1 Distribution of Taraxacum cristatum in Slovakia. Black dots - new localities (herbarium specimens, field research), empty dots - localities previously published by Vašut et al. (2005), grey dots - Taraxacum cf. cristatum. 


\section{List of revised voucher specimens}

\section{Pannonicum}

(Matricum): 2. Ipel'sko-rimavská brázda Region: Pláštovce, Šípka site, 280 m (Šuvada 2007 KO, 30688). - Modrý Kameň, Kalvária, near the path, 405 m (Šuvada 2008 KO, 30751). - Čebovce, forest-steppe over the village, $297 \mathrm{~m}$ (Šuvada PhD thesis (Msc.) 2010: 50). - Šurice, Soví castle, 233 m (Šuvada 2008 KO, 30687). - Drienčany, pasture W from the village, 256 m (Šuvada 2008 KO, 30746). - Drienčany, karst meadows above the village, $236 \mathrm{~m}$ (Majeský 2011 OL). - Drienčany, xerothermic vegetation around an abandoned stone-pit behind the village in the north-west direction, 236 m (Majeský 2011 OL). - Hrušovo, xerothermic vegetation around an abandoned stone-pit, ca. $1 \mathrm{~km}$ in front of the village from the south, $258 \mathrm{~m}$ (Majeský $2013 \mathrm{OL}$ ). - Hrušovo, karst meadows above the village, $270 \mathrm{~m}$ (Majeský 2013 OL). - Hrušovo, near stone-pit, $237 \mathrm{~m}$ (Šuvada 2008 KO, 30743). 3. Slovenský kras Karst: Brzotín, Brzotínske skaly rocks [in rupibus calcareis "Berzétei sziklak" supra opp. Rozsnyó], 650 m (Kárpáti 1939 BP, 400246). - Krásnohorské Podhradie, Krásna Hôrka castle, locus classicus, 448480 m (Vašut et al. 2005: 204; Šuvada 2008 KO, 30690; Dudáš 2012 OL). - Hrhov, Okrúhle hill, 244 m (Majeský et al. 2015: 2117). - Zádielske Dvorníky, Zemné Hradisko, pasture, 260 m (Dudáš 2012 OL). - Zádiel, on the top of limestone rocks of the Zádielska dolina valley, 600 m (Vašut et al. 2005: 209).

(Eupannonicum): 4. Záhorská nížina Lowland: Borský Svätý Jur, grassy sand on forest road (Pinetum), 168 m (Vašut et al. 2005: 209). - Malacky, sandy sites E from the city, 207 m (Šuvada 2008 KO, 30750). - Plavecký Štvrtok, grassy sand on the forest road between Malacky and Plavecký Štvrtok towns, 309 m (Vašut et al. 2005: 209). - Gbely, grassy sand on the forest road, $180 \mathrm{~m}$ (Pinetum) between the villages of Šaštín-Stráže and Borský Mikuláš, $180 \mathrm{~m}$ (Vašut et al. 2005: 209). - Borský Mikuláš, forest margin near the village (Vašut et al. 2005: 209). - Studienka, pine forest margin, $197 \mathrm{~m}$ (Majeský et al. 2015: 2118). 5. Devínska Kobyla Hills: Devínska Kobyla, W slope, ca. 200 m (Hubová 1966 SAV). 6. Podunajská nížina Lowland: Zlatná na Ostrove, Arcibiskupský Lél (Štěpánek 1988 PRC, 452522). - Čenkov, Čenkovská step (steppe), sandy lane (Majeský et al. 2015: 2117). 7. Košická kotlina Basin: Košice, Telek, orchard (Mikoláš 1999 KO, 24263, 24268, 24269). 8. Východoslovenská nížina Lowland: Malá Bara, Stredný vrch hill, in the middle belt of the field road and the pasture $\mathrm{S}$ from the village, 171 m (Šuvada 2008 KO, 30689; Dudáš 2016 OL; Dudáš 2017 KO, 34007; Dudáš 2017 BRNU, 656707). - Ladmovce, Kašvár, limestone, 140 m (Dudáš 2012 KO, 31076, 2n 3x; Dudáš 2015 OL; Majeský et al. 2015: 2117). - Malý Horeš, 
the meadow with steppe vegetation NE from the village, $118 \mathrm{~m}$ (Majeský et al. 2015: 2117). - Vel'ký Kamenec, pastures (Májovský 1964 SLO, T. cf. cristatum).

\section{Carpaticum occidentale}

(Praecarpaticum): 10. Malé Karpaty Mts.: Čachtice, Čachtice castle (Eliáš jun. 2009 NI). 11. Považský Inovec Mts.: Tematínské vrchy Hills, road Tematín - Lúka, steppe meadow (Vašut et al. 2005: 209; Majeský et al. 2015: 2117). (Trenčianske) Jastrabie, roadside, on loess, ca. 320 m (Vašut et al. 2005: 209). 12. Tribeč Mts.: Dolné Štitáre (Chrtek sen. \& Kř́sa 1965 PRC, 402148). - Zlatno, NE, forest roadside, beech forest (Kusák 1987 OLM, 159950, T. cf. cristatum). 13. Strážovské and Súl'ovské vrchy Mts.: Dubnica nad Váhom, in the grass on the dike lining the Váh river, 227 m (Majeský 2017 OL). - Partizánske, Hradište (Vašut et al. 2005: 209). - Omšenie, Sokolovica tourist sightseeing point, pine forest, limestone, 654 m (Dudáš 2017 KO, 34004; Fig. 2). - Omšenie, Mt. Baba, meadow on the top, limestone, 668 m (Dudáš 2017 KO, 34003). 15. Slovenské Rudohorie Mts.: Tŕstie, Korimovo (Futák \& Zahradníková 1940 SAV). - Lipovec, pastures NW from the village (Kliment 1977 SAV). 18. Stredné Pohornádie Valley: Malá Lodina, Ružín train station, xerothermic pasture over collective farm, field road near the yellow tourist path (Dudáš 2016 OL; Dudáš 2017 KO, 34008, 34024). Malá Lodina, Ružín, pastures under the crest of Ružínske skaly rocks (Mikoláš 1993 KO, 34124; Mikoláš 1998 KO, 20057, 20065, 33393).

(Eucarpaticum): 21a. Lúčanská Malá Fatra Mts.: Kláštor pod Znievom, Zniev (Vašut et al. 2005: 209). - Kláštor pod Znievom, in grassland (Vašut et al. 2005: 209). - Kláštor pod Znievom, Kalvária, near Panna Mária spring, S slope (Škovirová 1997 TM). - Žiar Mts., Jasenovo, Vyšehrad hill, rocks on the top, 829 m (Dudáš 2017 KO, 34002, T. cf. cristatum).

(Intracarpaticum): 25. Turčianska kotlina Basin: Mošovce, pasture (Vašut et al. 2005: 209).

(Beschidicum occidentale): 27b. Javorníky Mts.: Udiča, Mt. Klapy, meadow on the top, 654 m (Dudáš 2017 KO, 34005).

(Beschidicum orientale): 30c. Nízke Beskydy Mts.: Brekov, Brekov castle, limestone rocks under eastern wall, trampled site (Hadinec 1977 PRC, 402149; Dudáš 2017 KO, 34006, 34009).

\section{Discussion}

Taraxacum scanicum group is morphologically well-defined group of ca. 16 apomictic microspecies preferring usually dry or xerothermic biotopes, such as 


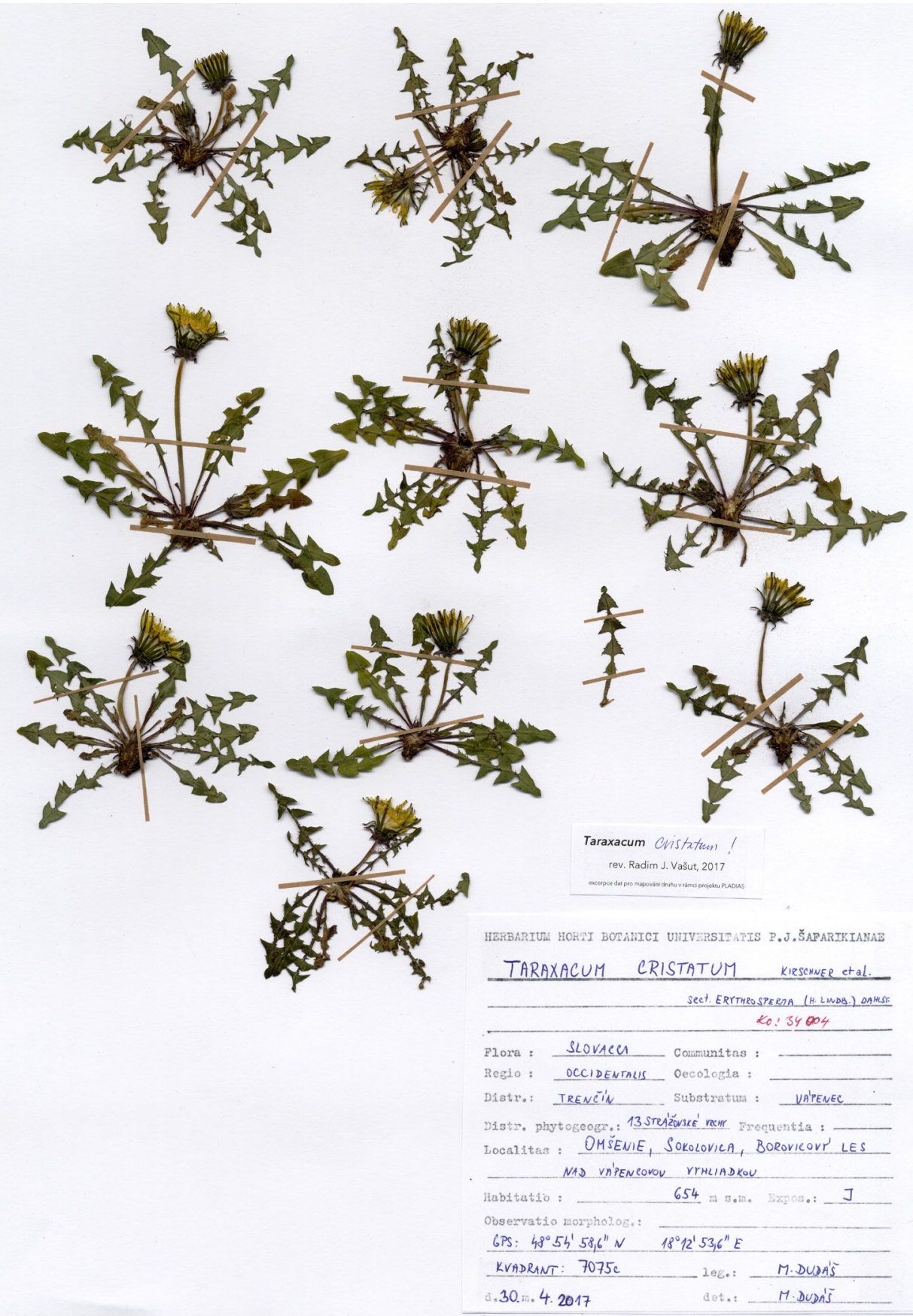

Fig. 2 Typical plants of T. cristatum from Strážovské vrchy Mts., herbarium specimen deposited in KO. 
sandy dunes, rocky slopes and xerothermic grasslands in western and northern Europe (Doll 1973). In Central Europe there are several morphotypes sharing the morphological characteristics of $T$. scanicum Dahlst., however, they differ in other features (teeth of lobes, colour of achenes, position of outer bracts etc.). Within this group, the species the most similar to T. cristatum are T. pudicum Vašut \& Majeský, T. scanicum and T. disseminatum G. Hagl. Nevertheless, all of the three species occur very rarely in Slovakia (they are known only from few sites). In the area of Slovakia, the species the most similar to T. cristatum are T. prunicolor Schmid et al., T. plumbeum Dahlst. and T. pudicum (the last two species occur very rarely in Slovakia). The main differences among $T$. cristatum and other species of $T$. scanicum group were mentioned in the work of Vašut et al. (2005, Table 2). T. cristatum has elongate-lingulate terminal lobe apex, 2-4(5) lateral lobes, the upper margin of the lateral lobes is often dentate (see Fig. 2), outer bracts are lanceolate and spreading and achenes are brown.

Taraxacum cristatum and T. pudicum (and some other species from sect. Erythrosperma, e.g. T. danubium) are central European species with the occurrence concentrated in the western part of Pannonian lowland, which is in the contrast to the distribution of western and northern European species as T. prunicolor and T. scanicum (Uhleman 2003; Schmid et al. 2004; Vašut et al. 2005).

In Slovakia, the distribution of $T$. cristatum is concentrated to the western and the southern parts of the country. From the easternmost Slovakia only four recent populations are known. The species grows in natural dry and xerothermic steppe grasslands, pastures and dry meadows belonging to the class Festuco-Brometea in the Festucion valesiacae and Koelerio-Phleion phleoidis alliances. It is the most abundant in the lowlands with sandy soils (Záhorská and southern parts of Podunajská and Východoslovenská nížina), where it usually grows along the paths in open pine-, oak- and rarely beech-forests. Regionally it prefers calcareous soils (Slovenský kras Karst, Čachtice castle hill, Strážovské vrchy Mts., Mt. Klapy and Brekov castle hill), where it grows between the limestone rocks in trampled sites and in sightseeing points. Rarely, it was found on volcanic substrates (Soví castle hill and few sites in the Zemplínske vrchy Mts.). The species was rarely recorded in dry ruderal sites as abandoned quarries and an old orchard, too.

The occurrence in planar and hilly level highly prevails. In Slovakia, the altitudinal maximum of $668 \mathrm{~m}$ a. s. I. was recorded in the Strážovské vrchy Mts. in the meadow between the limestone rocks on the top of Mt. Baba. The plants found on the top of Vyšehrad hill (Žiar Mts.) in the altitude of $829 \mathrm{~m}$ a. s. I. need further study. Vašut et al. (2005) mentioned $710 \mathrm{~m}$ a. s. I. as the highest 
altitudinal record for this species from the Czech Republic. Other known locations in Austria, Hungary and Poland occur mostly in lowlands in lower altitudes (Vašut et al. 2005; Marciniuk et al. 2009).

\section{Notes on the protection of the species}

The species has not been listed in the recent Red list of ferns and flowering plants in Slovakia (Eliáš et al. 2015). Although many suitable sandy and limestone areas across Slovakia exist, the species seem to be not frequent (scarce and probably overlooked) in comparison with more frequent species in Slovakia as Taraxacum erythrospermum Andrz. and/or T. parnassicum Dahlst.. The number of known locations is not high and the most of populations reach low number of individuals. However, regionally the high number of locations has been found on sands in the Záhorská nižina Lowland and on limestone in the Slovenský kras Karst, where new populations are supposed to be find with a high probability. Besides this, two isolated, but numerous populations were found, first one in the pine forest on limestone on Sokolovica rock in the Strážovské vrchy Mts. and the second one on dry pasture over Ružín water reservoir (Stredné Pohornádie Valley). The species is probably more abundant in the large area of Ipel'skorimavská brázda Region. In several cases, the species occurs in the territories with different degree of area protection, as castle hills and nature reserves.

\section{Acknowledgement}

Thanks are due to J. Štěpánek (Prague, Průhonice, Czech Republic) and R. J. Vašut (Olomouc, Czech Republic) for revision of the herbarium material. I also thank to L. Mártonfiová (Košice, Slovakia) for the correction of English language, R. Šuvada (Rožňava, Slovakia) for information about the occurrence of the species in the Slovenský kras Karst, T. Miháliková (Bratislava, Slovakia) for creating the distribution map and L'. Majeský (Olomouc, Czech Republic) for kindly providing his collection. Thanks are due also to two anonymous reviewers for useful comments on earlier version of the manuscript.

\section{References}

Doll R. (1973): Revision der sect. Erythrosperma Dahlst. emend. Lindb. f. der Gattung Taraxacum Zinn. 2. Teil - Feddes Repert. 84: 1-180.

Eliáš P. jun., Dítě D., Kliment J., Hrivnák R. \& Feráková V. (2015): Red list of ferns and flowering plants of Slovakia, 5th edition (October 2014). - Biologia 70: 218-228. DOI: 10.1515/biolog-2015-0018 
Futák J. (1980): Fytogeografické členenie / Phytogeographical division (1: 1000 000). In: Mazúr E. (ed.): Atlas Slovenskej socialistickej republiky. - Slovenské pedagogické nakladatel'stvo, Bratislava.

Jarolímek I., Šibík J., Hegedüšová K., Janišová M., Kliment J., Kučera P., Májeková J., Michálková D., Sadloňová J., Šibíková I., Škodová I., Tichý L., Uhlírová J., Ujházy K., Ujházyová M., Valachovič M. \& Zaliberová M. (2008): A list of vegetation units of Slovakia. In: Jarolímek I. \& Šibík J. (eds). Diagnostic, constant and dominant species of the higher vegetation units of Slovakia. Veda, Bratislava, p. 295-329.

Kirschner J. \& Štěpánek J. 1995: Současný stav taxonomického výzkumu rodu Taraxacum v České a Slovenské republice. - Zpr. Čes. Bot. Společ. 29 (1994): 1-9.

Majeský L'., Vašut R. J. \& Kitner M. (2015): Genotypic diversity of apomictic microspecies of the Taraxacum scanicum group (Taraxacum sect. Erythrosperma). - Plant Syst. Evol. 301: 2105-2124. DOI 10.1007/s00606-015-1218-x

Marciniuk J., Vašut R. J., Marciniuk P. \& Czarna A. (2009): Taraxacum scanicum Dahlst. group (section Erythrosperma) in Poland: Chorology and seed and pollen morphology of the microspecies. - Acta Soc. Bot. Pol. 78 (2): 115-121.

Niklfeld H. (1971): Bericht über die Kartierung der Flora Mitteleuropas. - Taxon 20: 545571.

Schmid M., Vašut R. J. \& Oosterveld P. (2004): Taraxacum prunicolor spec. nova, a new species of the Taraxacum scanicum group (sect. Erythrosperma). - Feddes Repert. 115: 220-229. DOI: 10.1002/fedr.200311038

Šuvada R. (2010): Taxonómia rodu Taraxacum sect. Erythrosperma v panónskej oblasti (Msc.). Univerzita Komenského, Bratislava. 139 pp.

Šuvada R., Mártonfi P. \& Mártonfiová L. (2012): Differentiation of Diploid and Triploid Taxa within Taraxacum sect. Erythrosperma (Asteraceae) from the Pannonian Region. - Folia Geobot. 47: 69-91. DOI 10.1007/s 12224-011-9109-6

Thiers B. (2019): Index Herbariorum: A global directory of public herbaria and associated staff. - New York Botanical Garden's Virtual Herbarium, New York. http://sweetgum. nybg.org/ih/

Uhlemann I. (2003): Die Gattung Taraxacum (Asteraceae) im östlichen Deutschland. Mitt. Florist. Kart. Sachsen-Anhalt, Sonderheft 2003: 1-136.

Vašut R. J. (2003): Taraxacum sect. Erythrosperma in Moravia (Czech Republic): Taxonomic notes and the distribution of previously described species. - Preslia, Praha, 75: 311-338.

Vašut R. J., Štěpánek J. \& Kirschner J. (2005): Two new apomictic Taraxacum microspecies of the section Erythrosperma from Central Europe. - Preslia, Praha 77: 197-210. 